STATUS PARITAS DAN PEKERJAAN IBU TERHADAP PENGELUARAN ASI PADA IBU MENYUSUI 0-6 BULAN

\title{
(PARITY AND EMPLOYMENT STATUS TOWARDS BREAST MILK EXPENDITURE ON BREASTFEEDING MOTHER 0-6 MONTHS)
}

\section{Ratna Sari Hardiani}

Program Studi Ilmu Keperawatan Universitas Jember

Jalan Kalimantan No 37 Jember 68121

e-mail: ratna_sh@yahoo.com

\begin{tabular}{|c|c|}
\hline & ABSTRAK \\
\hline $\begin{array}{l}\text { Kata kunci: } \\
\text { ibu menyusui } \\
\text { paritas } \\
\text { pekerjaa } \\
\text { pengeluaran ASI }\end{array}$ & $\begin{array}{l}\text { Angka capaian ASI eksklusif masih belum bisa maksimal, meskipun target capaian di } \\
\text { Kabupaten Jember adalah } 80 \% \text {. Wilayah Arjasa merupakan salah satu wilayah dengan } \\
\text { cakupan ASI terendah sebesar } 14,40 \% \text {. Ketidaklancaran pengeluaran ASI menjadi salah } \\
\text { satu penyebab yang ditemukan. Penelitian ini bertujuan untuk mengetahui hubungan antara } \\
\text { status paritas dan pekerjaan ibu terhadap pengeluaran ASI pada ibu menyusui } 0-6 \text { bulan. } \\
\text { Penelitian ini merupakan studi korelasional dengan pendekatan cross sectional dengan } \\
\text { sampel sebanyak } 30 \text { ibu menyusui di wilayah Puskesmas Arjasa. Data dianalisis dengan } \\
\text { uji korelasi Spearman }(\mathrm{p}<0,05 \text { ). Hasil penelitian menunjukkan bahwa sebagian besar ibu } \\
\text { primipara dengan status pekerjaan buruh tani, dan sebagian besar pengeluaran ASI tidak } \\
\text { lancar. Status pekerjaan ibu mempunyai korelasi dengan pengeluaran ASI ( } \mathrm{p}=0,017) \text {, sta- } \\
\text { tus paritas tidak berhubungan terhadap pengeluaran ASI ( } \mathrm{p}=0,517) \text {. Pekerjaan ibu dapat } \\
\text { mempengaruhi pengeluaran ASI, disarankan agar petugas kesehatan meningkatkan } \\
\text { pendidikan kesehatan dan pemberian motivasi tentang manajemen laktasi baik pada ibu } \\
\text { bekerja maupun tidak bekerja dengan melibatkan dukungan keluarga. }\end{array}$ \\
\hline
\end{tabular}

\section{ABSTRACT}

Keywords:

breastfeeding

breast milk expen-

diture

The achievement of exclusive breastfeeding is still not reach the maximum target, although the achievement target in Jember is $80 \%$. Arjasa is one of districts with the lowest breastfeeding coverage, its amount to $14.40 \%$. Discontinuity of breastfeeding expenditure became one of the causes. This research explained the employment status parity correlation of parity and employment with breast milk expenditure on breastfeeding mother 0-6 months. This research was a correlation study with cross sectional approach which consisted of 30 breastfeeding mothers in Public Health Center of Arjasa, Jember. Data were analyzed by Spearman Rho test $(p<0.05)$. The results showed that most of mothers were primiparous and farm labor as employment, and the majority of breast milk expenditure was not smooth. Mother's employment status had a correlation with breastfeed expenditure $(p=0.017)$, whereas parity didn't have correlation to breastfeed expenditure $(p=0.517)$. Based on the results, mother's employment can affect the breast milk expenditure. Health workers should improve health education and motivation about breast milk management on breastfeeding mothers involving their family support. 


\section{PENDAHULUAN}

Makanan atau nutrisi yang sehat pada bayi yang memenuhi kualitas dan kuantitas yang memadai, yaitu air susu ibu (ASI) (Ramaiah, 2007). ASI merupakan nutrisi yang paling tepat diberikan pada bayi baru lahir sampai umur 6 bulan karena pada masa tersebut usus bayi belum mampu mencerna makanan selain ASI. ASI merupakan susu segar dan steril yang diproduksi langsung oleh ibu dan dapat mengurangi gangguan gastrointestinal dibandingkan dengan makanan lain jika diminum oleh bayi. ASI juga mengandung nutrisi, hormon, unsur kekebalan, faktor pertumbuhan, anti alergi, antibodi serta anti inflamasi yang dapat mencegah terjadinya infeksi pada bayi (Purwanti, 2004).

Proses menyusui akan memberikan dampak yang baik seperti pada proses awal menyusui, setelah bayi lahir terdapat zat kekebalan tubuh yang terdapat pada kolostrum yang kaya akan protein dan mengandung imunoglobulin A yang keluar pertama kali melalui ASI pada hari pertama sampai ke 3-5 (Suradi, 2008). Proses pengeluaran ASI dapat terjadi karena adanya refleks menghisap juga dapat dipengaruhi proses hormonal terutama oksitosin dan prolaktin (Hidayat, 2009). Bayi yang tidak mendapatkan ASI akan mengalami peningkatan resiko infeksi pernapasan dan infeksi gastrointestinal, mengganggu pertumbuhan dan perkembangan dan pertahanan tubuh yang kurang baik (Takasihaeng, 2005). Purwanti (2003) mengatakan bahwa anak yang mendapatkan ASI sampai usia 6 bulan jauh lebih sehat dibandingkan anak yang mendapatkan ASI sampai usia 4 bulan, dan frekuensi terkena diare jauh lebih kecil.

Berdasarkan Susenas 2009 terdapat 61,3\% bayi usia 0-5 bulan yang mendapatkan ASI eksklusif dengan rentang terendah dan tertinggi, antara $48,8 \%$ sampai $78 \%$. Provinsi dengan cakupan tertinggi yaitu Nusa Tenggara Barat, Bengkulu, dan Nusa Tenggara Timur. Sedangkan provinsi dengan cakupan terendah adalah Jawa Timur, Jawa Tengah, dan Aceh (Profil Kesehatan Indonesia, 2010). Kabupaten Jember merupakan salah satu kabupaten yang pencapaian ASI eksklusifnya dibawah standar yang ditetapkan pemerintah Kabupaten Jember yaitu sebesar $60 \%$. Cakupan ASI eksklusif terendah yaitu puskesmas Rowotengah sebesar 12,26\%, puskesmas Arjasa sebesar 14,50\%, puskesmas Rambipuji 31,28\%, puskesmas Gladakpakem sebesar 33,19\%, dan puskesmas Balung sebesar 36,12\% (Dinas Kesehatan Kabupaten Jember, 2012). Target pencapaian ASI eksklusif masih sulit dicapai secara optimal disebabkan beberapa hal diantaranya adalah gangguan atau ketidaklancaran pengeluaran ASI (Sulistyoningsih, 2011; Naylor et al, 2009). Ketidaklancaran pengeluaran ASI itu sendiri dapat disebabkan oleh beberapa faktor baik faktor fisik maupun psikologis. Produksi ASI sangat dipengaruhi oleh faktor kejiwaan karena perasaan ibu dapat menghambat atau meningkatkan pengeluaran oksitosin, bila ibu dalam keadaan tertekan, sedih, kurang percaya diri dan berbagai bentuk ketegangan emosional dapat menurunkan produksi ASI (Sulistyoningsih, 2011; Naylor et al, 2009).

Beberapa faktor yang mempengaruhi pengeluaran ASI di antaranya perubahan sosial budaya, faktor psikologis, faktor fisik ibu, meningkatnya promosi susu formula, factor petugas kesehatan, makanan ibu, berat badan lahir bayi, penggunaan alat kontrasepsi. Perubahan sosial budaya dimana ibu-ibu yang bekerja atau ibu-ibu yang mempunyai kesibukan lainnya, meniru teman atau tetangga yang menggunakan susu botol, merasa ketinggalan zaman jika menyusui. Produksi ASI sangat dipengaruhi oleh faktor kejiwaan karena perasaan ibu dapat menghambat atau meningkatkan pengeluaran oksitosin, bila ibu dalam keadaan tertekan, sedih, kurang percaya diri dan berbagai bentuk ketegangan emosional dapat menurunkan produksi ASI. sehingga ibu yang sedang menyusui sebaiknya jangan terlalu banyak dibebani oleh urusan pekerjaan rumah tangga, urusan kantor, dan lainnya. Berdasarkan uraian di atas, peneliti tertarik untuk mengkaji lebih jauh ada tidaknya hubungan antara status paritas dan pekerjaan ibu terhadap pengeluaran ASI pada ibu menyusui di area Puskesmas Arjasa Kabupaten Jember.

\section{METODE}

Penelitian ini adalah studi korelasional dengan menggunakan pendekatan cross sectional. Sebanyak 30 ibu menyusui bayi 0-6 bulan pada Juni 2012 diambil sebagai sampel yang telah memenuhi kriteria penelitian dengan purposive sampling. Kriteria inklusi meliputi: ibu dengan riwayat persalinan fisiologis, ibu menyusui 0-6 bulan, bertempat tinggal dan menetap di wilayah kerja puskesmas arjasa, ibu dalam keadaan sehat fisik dan mental dan bersedia menjadi responden. Kriteria eksklusi meliputi: ibu yang sedang sakit, bayi yang telah mendapatkan susu formula, ibu mengkonsumsi obata-obatan atau jamu dieksklusi dari penelitian ini.

Variabel status paritas adalah banyaknya kelahiran hidup yang dipunyai oleh seorang wanita 
(Suparyanto, 2010) dan dikategorikan menjadi primipara, multipara dan grandemultipara (Prawirohardjo, 2002). Masing-masing kategori diberikan kode 1 untuk primipara, 2 untuk multipara dan 3 untuk grandemultipara. Pengambilan data variabel independen berdasarkan data primer wawancara dengan ibu dan data sekunder catatan kelahiran. Status pekerjaan ibu didapatkan dari wawancara dengan ibu dan informasi petugas. Status pekerjaan ditentukan berdasarkan ibu yang bekerja (petani dan swasta) dan tidak bekerja (ibu rumah tangga). Ibu yang tidak bekerja adalah ibu rumah tangga yang tidak memiliki penghasilan tambahan dan ibu bekerja berdasarkan UU 13 tahun 2003 ketenagakerjaan adalah ibu yang mempunyai pekerjaan tetap setiap harinya dengan minimal 7 jam kerja setiap hari untuk 6 hari kerja dalam 1 minggu atau 8 jam per hari untuk 5 hari kerja dalam 1 minggu. Ibu yang tidak bekerja diberikan skor 1 dan ibu bekerja diberikan skor 2. Variabel pengeluaran ASI adalah Penilaian dan observasi ibu tentang keluarnya ASI dari payudara ibu ke mulut bayi dinilai berdasarkan instrumen kuesioner yang terdiri dari pertanyaan favorable dan unfavorable. Hasil penilaian dikategorikan menjadi dua yaitu lancar dan tidak lancar, berdasarkan cut of point data yaitu pada angka 89, sehingga nilai di atas cut of point dikategorikan sebagai ASI lancar dan di bawah cut of point dikategorikan sebagai ASI tidak lancar.

Analisa data penelitian menggunakan korelasi Spearman's Rho dengan $\mathrm{p}=0,05$ (CI 95\%). Dikatakan ada hubungan yang bermakna jika nilai $\mathrm{p}$ $<0,05$ dan tidak ada hubungan yang bermakna antara dua variabel jika nilai $p>0,05$. Kekuatan korelasi (nilai r) ditentukan menjadi beberapa nilai kekuatan hubungan yaitu kekuatan korelasi: sangat kuat $(0,80$ $1,00)$, kuat $(0,60-0,799)$, sedang $(0,40-0,599)$, lemah $(0,20-0,399)$, sangat lemah $(0,00-0,199)$ (Dahlan, 2006).

\section{HASIL}

\section{Karakteristik Responden}

Tabel 1 menunjukkan bahwa responden paling banyak berusia 20-25 tahun sebanyak 22 orang (73,3\%), pendidikan sebagian besar SD sebanyak 15 orang (50\%). Pekerjaan responden paling banyak adalah ibu tidak bekerja/ibu rumah tangga sebanyak 22 orang $(73,3 \%)$, penghasilan keluarga pada rentang Rp 500.000 sampai Rp 1.000.000. Jenis kelamin bayi sebagian besar perempuan sebanyak 20 bayi $(66,7 \%)$ yang sebagian besar berumur 0 bulan yaitu 17 bayi atau $56,7 \%$.

Tabel 2 menunjukkan bahwa status paritas sebagian besar responden adalah primipara yaitu sebanyak 22 responden $(73,3 \%)$, dan sebagian kecil adalah multipara sebanyak 8 responden $(26,7 \%)$ dan tidak didapatkan grandemultipara.

Tabel 3 menunjukkan bahwa pengeluaran ASI pada responden sebanyak 60\% (18 orang) pengeluaran ASI lancar, sedangkan sisanya sebesar $40 \%$ (12 orang) pengeluaran ASI tidak lancar.

Berdasarkan data pada tabel 4 menunjukkan bahwa sebanyak 8 responden primipara mengalami pengeluaran ASI lancar (26,67\%), dan sebanyak 14 responden primipara mengalami pengeluaran ASI tidak lancar (46,67\%). Sedangkan pada responden multipara menunjukkan masing-masing ada 4 responden yang mengalami pengeluaran ASI lancar dan tidak lancar $(13,33 \%)$. Hasil uji statistik menunjukkan nilai $\mathrm{p}$ value $0,517>\mathrm{p}=0,05$ dengan CI 95\% dan kekuatan korelasi r sebesar 0,123 maka dapat disimpulkan tidak ada hubungan signifikan antara status paritas dan pengeluaran ASI.

Berdasarkan data pada tabel 5 menunjukkan bahwa sebanyak 6 responden yang bekerja mengalami pengeluaran ASI lancar (20\%), dan sebanyak 2 responden yang bekerja mengalami pengeluaran ASI tidak lancar (6,67\%). Sedangkan pada responden yang tidak bekerja menunjukkan ada 6 responden pengeluaran ASI lancar (20\%) dan 16 responden menunjukkan pengeluaran ASI tidak lancar $(53,33 \%)$. Hasil uji statistik menunjukkan nilai p value $0,017<\mathrm{p}=0,05$ dengan CI 95\% dan kekuatan korelasi $\mathrm{r}$ sebesar 0,431 maka dapat disimpulkan bahwa ada hubungan antara status pekerjaan dan pengeluaran ASI dengan kekuatan hubungan sedang $(0,40-0,599)$.

\section{PEMBAHASAN}

Pengeluaran ASI merupakan suatu interaksi yang sangat komplek antara rangsangan mekanik, saraf dan berbagai hormon (Soetjiningsih, 2001). Pengeluaran ASI tidak lancar pada sebagian besar responden dapat dipengaruhi oleh beberapa faktor. Hasil penelitian menunjukkan bahwa pengeluaran ASI tidak lancar terjadi pada sebagian besar responden primipara dengan status pekerjaan tidak bekerja dan sebagai ibu rumah tangga. Status paritas responden sebagian besar adalah primipara. Paritas yang menggambarkan jumlah kelahiran dari seorang wanita, tidak berpengaruh secara langsung pada pengeluaran ASI. Secara statistik pada penelitian mungkin dapat dipengaruhi oleh perbedaan jumlah responden dimana primipara lebih mendominasi. Secara konsep paritas dapat berpengaruh secara tidak langsung pada proses menyusui dan pengeluaran ASI, hal ini karena adanya 
Tabel 1. Distribusi Frekuensi Karakteristik Responden ( $\mathrm{n}=30)$

\begin{tabular}{|c|c|c|c|}
\hline & & & \\
\hline No & Karakteristik resp onden & Jumlah (orang) & Prosentase $(\%)$ \\
\hline 1. & Umur (tahun) & & \\
\hline & a. $20-25$ & 22 & 73,3 \\
\hline & b. $26-30$ & 6 & 20,0 \\
\hline & c. $31-35$ & 2 & 6,7 \\
\hline & Total & 30 & 100 \\
\hline 2. & Pendidikan terakhir ibu & & \\
\hline & 1. Tidak sekolah & 7 & 23,3 \\
\hline & 2. SD & 15 & 50,0 \\
\hline & 3. SMP & 5 & 16,7 \\
\hline & 4. SMA & 3 & 10,0 \\
\hline & Total & 30 & 100 \\
\hline 3. & Pekerjaan Ibu & & \\
\hline & 1. Tidak bekerja (Ibu rumah tangga) & 22 & 73,3 \\
\hline & 2. Bekerja & 8 & 26,6 \\
\hline & - Petani & 4 & \\
\hline & - Swasta & 4 & \\
\hline & Total & 30 & 100 \\
\hline 4. & Penghasilan Keluarga & & \\
\hline & 1. $<500000$ & 12 & 40,0 \\
\hline & 2. $500000-100000$ & 15 & 50,0 \\
\hline & 3. $>100000$ & 3 & 10,0 \\
\hline & Total & 30 & 100 \\
\hline 5. & Jenis Kelamin & & \\
\hline & a. Perempuan & 20 & 66,7 \\
\hline & b. Laki-laki & 10 & 33,3 \\
\hline & Total & 30 & 100 \\
\hline 6. & Umur Bayi (bln) & & \\
\hline & a. 0 & 17 & 56,7 \\
\hline & b. 1 & 7 & 23,3 \\
\hline & c. 2 & 5 & 16,7 \\
\hline & d. 3 & 1 & 3,3 \\
\hline & Total & 30 & 100 \\
\hline
\end{tabular}

Tabel 2. Distribusi Frekuensi Responden Berdasarkan Status Paritas $(\mathrm{n}=30)$.

\begin{tabular}{cccc}
\hline & Status Paritas & Jumlah (orang) & Prosentase (\%) \\
\hline a. & Primipara & 22 & 73,3 \\
b. & Multipara & 8 & 26,7 \\
c. & Grandemultipara & - & - \\
\hline & Total & $\mathbf{3 0}$ & $\mathbf{1 0 0}$ \\
\hline
\end{tabular}

Tabel 3. Distribusi Frekuensi Responden Berdasarkan Pengeluaran ASI (n=30).

\begin{tabular}{|c|c|c|}
\hline Pengeluaran ASI & Jumlah (orang) & Prosentase (\%) \\
\hline a. Lancar & 12 & 40 \\
\hline b. Tidak Lancar & 18 & 60 \\
\hline Total & 30 & 100 \\
\hline
\end{tabular}


Tabel 4. Distribusi Responden Berdasarkan Hubungan Status Pekerjaan Dan Pengeluaran ASI (n=30)

\begin{tabular}{|c|c|c|c|c|c|c|c|c|}
\hline \multirow{3}{*}{$\begin{array}{l}\text { Status } \\
\text { Paritas }\end{array}$} & \multicolumn{4}{|c|}{ Kelancaran Pengeluaran ASI } & \multirow{2}{*}{\multicolumn{2}{|c|}{ Total }} & \multirow[t]{3}{*}{$\mathbf{R}$} & \multirow{3}{*}{$\begin{array}{l}P \\
\text { value }\end{array}$} \\
\hline & \multicolumn{2}{|c|}{ Lancar } & \multicolumn{2}{|c|}{ Tidak lancar } & & & & \\
\hline & $\mathbf{F}$ & $\%$ & $\mathbf{F}$ & $\%$ & $\mathbf{F}$ & $\%$ & & \\
\hline Primipara & 8 & 26,67 & 14 & 46,67 & 22 & 73,34 & 0,123 & 0,517 \\
\hline Multipara & 4 & 13,33 & 4 & 13,33 & 8 & 26,66 & & \\
\hline Jumlah & 12 & 41,8 & 18 & 58,2 & 30 & 100 & & \\
\hline
\end{tabular}

Tabel 5. Distribusi Responden Berdasarkan Hubungan Status Pekerjaan Dan Pengeluaran ASI ( $\mathrm{n}=30)$

\begin{tabular}{|c|c|c|c|c|c|c|c|c|}
\hline \multirow{3}{*}{$\begin{array}{l}\text { Status } \\
\text { Pekerjaan }\end{array}$} & \multicolumn{4}{|c|}{ Kelancaran Pengeluaran ASI } & \multirow{2}{*}{\multicolumn{2}{|c|}{ Total }} & \multirow[t]{3}{*}{$\mathbf{R}$} & \multirow{3}{*}{$\begin{array}{l}P \\
\text { value }\end{array}$} \\
\hline & \multicolumn{2}{|c|}{ Lancar } & \multicolumn{2}{|c|}{ Tidak lancar } & & & & \\
\hline & $\mathbf{F}$ & $\%$ & $\mathbf{F}$ & $\%$ & $\mathbf{F}$ & $\%$ & & \\
\hline Bekerja & 6 & 20 & 2 & 6,67 & 8 & 26,67 & 0,431 & 0,017 \\
\hline $\begin{array}{l}\text { Tidak } \\
\text { Bekerja } \\
\end{array}$ & 6 & 20 & 16 & 53,33 & 22 & 73,33 & & \\
\hline Jumlah & 28 & 41,8 & 39 & 58,2 & 30 & 100 & & \\
\hline
\end{tabular}

faktor-faktor eksternal yang turut mempengaruhi seperti pengetahuan, budaya dan keyakinan, juga pengalaman sebelumnya yang telah didapat (Khoiriyah, 2011). Paritas ada kaitannya dengan arah pencarian informasi tentang pengetahuan ibu dalam menyusui. Pengalaman yang diperoleh ibu dapat memperluas pengetahuan seseorang dalam pemberian ASI. Bahwa pengalaman ibu dalam mengurus anak berpengaruh terhadap pengetahuan tentang ASI eksklusif(Soetjiningsih, 1997).

Status pekerjaan responden menunjukkan mayoritas responden tidak bekerja (sebagai ibu rumah tangga). Tugas seorang ibu rumah tangga sangat banyak diantaranya yitu memasak, mencuci, mengurus anak dan suami. Hal ini mengakibatkan kelelahan atau letih pada ibu yang memicu penurunan produksi ASI. Ibu yang mengalami stres maka akan terjadi blokade dari refleks letdown. Hal ini disebabkan karena adanya pelepasan dari adrenalin (epinefrin) yang menyebabkan vasokonstriksi pembuluh darah alveoli sehingga akan menghambat oksitosin untuk dapat mencapai target organ mioepitelium. Refleks letdown yang tidak sempurna akan menyebabkan penumpukan air susu di dalam alveoli yang secara klinis tampak payudara membesar (Soetjiningsih, 2001). Rohani (2007) mengatakan bahwa pekerjaan ibu berpengaruh terhadap pemberian ASI eksklusif.

Beberapa faktor lain juga dapat mempengaruhi pengeluaran ASI. Faktor pertama yaitu kurangnya pengetahuan pada responden. Didapatkan bahwa mayoritas responden berpendidikan SD. Menurut Notoatmodjo (2007), semakin tinggi pendidikan seseorang, juga semakin mudah menerima informasi sehingga makin banyak pengetahuan yang dimiliki. Afifah mengatakan bahwa pengetahuan ibu menjadi penyebab gagalnya pemberian ASI eksklusif. Rohani (2009) mengatakan bahwa faktor pengetahuan mempunyai pengaruh terhadap pemberian ASI eksklusif $(p=0,002)$. Hal agak berbeda disampaikan oleh Anggrita (2010) yang mengatakan bahwa tidak ada hubungan yang bermakna antara tingkat pendidikan ibu menyusui dengan pemberian ASI eksklusif $(\mathrm{p}=0,314)$. Responden yang melakukan pemberian ASI eksklusif pada bayinya lebih banyak dijumpai pada tingkat pendidikan sedang (100\%), sedangkan tidak dijumpai pada pendidikan rendah dan pendidikan tinggi. Penelitian tersebut didukung oleh Elmiyasna (2009) yang menyatakan bahwa tidak ada kaitan antara pendidikan ibu dengan pemberian ASI eksklusif. Hal tersebut disebabkan karena pendidikan yang diterima seseorang akan mempengaruhi pengetahun, karena pendidikan seseorang tidak hanya dipengaruhi oleh pendidikan formal tetapi juga pendidikan yang dipengaruhi oleh pendidikan informal (seperti pengalaman).

Pengetahuan yang kurang dan budaya yang salah dapat menjadi penghambat. Banyak ibu baik yang baru melahirkan maupun sudah sering melahirkan tidak memberikan kolostrum kepada bayinya. Di berbagai daerah, air susu pertama (kolostrum) sengaja diperah dengan tangan dan dibuang. Mereka percaya dan berpendapat bahwa 
kolostrum akan berpengaruh buruk terhadap kesehatan anak (Nasihah, 2010). Pengetahuan yang baik diharapkan dapat meningkatkan kesadaran dan kemampuan ibu dalam mengelola dan mempergunakan waktu, aktivitas atau kesibukan dan sumber yang dimiliki sebaik mungkin sehingga manajemen ASI yang baik dapat tercapai dan pengeluaran ASI lancar.

Faktor berikutnya yaitu psikologis ibu, dimana kurangnya dukungan keluarga merupakan salah satu penyebab gagalnya pemberian ASI eksklusif. Sebagian besar responden yang tidak bekerja (ibu rumah tangga) suami bekerja di luar kota dan hanya pulang seminggu atau beberapa bulan sekali. Hal tersebut dapat memicu ketegangan internal dalam tubuh ibu karena relatif menangani semuanya sendiri atau memikirkan keberadaan suami yang berada di tempat yang jauh.

Perasaan ibu dapat menghambat atau meningkatkan pengeluaran oksitosin, bila ibu dalam keadaan tertekan, sedih, kurang percaya diri dan berbagai bentuk ketegangan emosional maupun penurunan fisik seperti karena kelelahan dapat menurunkan produksi ASI, sehingga ibu yang sedang menyusui sebaiknya jangan terlalu banyak dibebani oleh urusan pekerjaan rumah tangga (Sulistyoningsih, 2011). Status pekerjaan dari responden dan juga suami akan berpengaruh pada pendapatan keluarga. Dapat dilihat dari data pendapatan yang sebagian besar berada di rentang Rp 500.00 sampai Rp 1.000.00 dimana kondisi ini dapat dikatakan bahwa secara umum masih di bawah UMR daerah. Adanya tuntutan kebutuhan yang semakin meningkat seiring bertambahnya usia bayi, pekerjaan sehari-hari, serta kecukupan finansial dapat menjadi stresor tersendiri bagi seorang ibu.

Kemampuan bayi dalam menghisap ASI yang lemah berpengaruh terhadap produksi ASI yang juga akan berpengaruh terhadap volume ASI. Kemampuan menghisap bayi tersebut secara tidak langsung juga didukung oleh usia dan jenis kelamin bayi. Ketika bayi menghisap payudara ibu, ujung saraf yang ada di puting dirangsang dan rangsangan tersebut oleh serabut afferent di bawa ke hipotalamus yang berada di dasar otak, lalu memicu hipofise anterior untuk mengeluarkan hormon prolaktin ke dalam darah. Meningkatnya hormon prolaktin di dalam darah akan merangsang kelenjar penghasil ASI dalam payudara untuk menghasilkan ASI dalam jumlah yang lebih banyak sehingga jumlah ASI yang dihasilkan tergantung pada isapan bayi pada payudara ibu, jadi makin sering rangsangan penyusuan makin banyak pula produksi ASI (Ramaiah, 2007).

\section{SIMPULAN}

Simpulan penelitian bahwa ada hubungan antara status pekerjaan dengan pengeluaran ASI ibu menyusui 0-6 bulan. Pekerjaan ibu dapat berpengaruh terhadap kelancaran pengeluaran ASI jika menimbulkan stres, ketegangan, atau tertundanya pemberian ASI dalam waktu lama. Paritas ibu didapatkan tidak berpengaruh terhadap pengeluaran ASI yang mungkin dapat lebih dipengaruhi oleh faktor lain seperti status kesehatan fisik dan psikis dari ibu dan bayi.

\section{SARAN}

Perlu dilakukan penelitian lebih lanjut tentang pengalaman dan budaya pada status paritas yang berbeda terhadap pengeluaran ASI, juga perlunya intervensi yang ramah budaya dan praktis yang dapat digunakan oleh ibu bekerja maupun tidak untuk meningkatkan pengeluaran ASI. Petugas kesehatan diharapkan meningkatkan pendidikan kesehatan, motivasi dan pendampingan kedalam manajemen laktasi baik pada ibu bekerja maupun tidak bekerja dengan melibatkan dukungan keluarga dan sumbersumber yang dimiliki oleh ibu.

\section{KEPUSTAKAAN}

Afifah, Nur Diana. 2007. Faktor yang Berperan dalam Kegagalan Praktik Pemberian ASI Eksklusif. Tesis. Online serial. http:// eprints.undip.ac.id/17024/1/ Diana_Nur_Afifah.pdf

Alkatiri, S. 1996. Kajian Imunoglobulin Dalam ASI. Surabaya: Airlangga University Press.

Anggrita, Kiki. 2009. Hubungan Karakteristik Ibu Menyusui terhadap Pemberian ASI Eksklusif di Wilayah Kerja Puskesmas Medan Amplas tahun 2009. Skripsi. Online serial. http://repository.usu.ac.id/ bitstream/handle/123456789/14284/ 10E01058.pdf?sequence $=1$

Arikunto, S. 2006. Prosedur Penelitian Suatu Pendekatan Praktik. Edisi Revisi VI. Jakarta: Rineka Cipta.

Dahlan, MS. 2006. Statistik untuk Kedokteran dan Kesehatan Uji Hipotesis dengan Menggunakan SPSS. Jakarta: PT. Arkans

Departemen Kesehatan RI. 2011. Rencana Strategis Dinas Kesehatan Propinsi Jawa Timur Tahun 2009-2014. Jakarta: Depkes RI. 
Dinas Kesehatan Kabupaten Jember. 2011. Profil Kesehatan Kabupaten Jember 2010. Jember: Badan Penerbit Dinas Kesehatan Kabupaten Jember.

Dinas Kesehatan Kabupaten Jember. 2012. Profil Kesehatan Kabupaten Jember 2011. Jember: Badan Penerbit Dinas Kesehatan Kabupaten Jember.

Elmiyasna. 2009. Kajian Pemberian ASI Eksklusif Kaitannya Dengan Pendidikan Dan Pekerjaan Ibu Menyusui Di Puskesmas Nanggolo Padang. Artikel Penelitian. Padang: STIKES Mercu Bakti Jaya.

Hassan, R., et al. 2002. Ilmu Kesehatan Anak. Jakarta: Universitas Indonesia.

Hidayat, Aziz Alimul. 2009. Pengantar Ilmu Keperawatan Anak Buku 1. Jakarta: Salemba Medika

Husaini, Y. 2001. Makanan Bayi Bergizi. Yogyakarta: Gadjah Mada University Press.

Indiarti \& Bertiani. 2009. Nutrisi Bayi Sejak Dalam Kandungan Sampai Usia 1 Tahun. Yogyakarta: Cahaya Ilmu

IDAI. 2013. ASI Sebagai pencegah malnutrisi pada bayi. Online. http://idai.or.id/artikel/klinik/ asi/asi-sebagai-pencegah-malnutrisipada-bayi

Indra, L. 2009. Hubungan Tingkat Kecemasan Ibu Post Partum Primipara dengan Kelancaran Pengeluaran ASI di Ruang Nifas RSD dr. Soebandi jember. Tidak diterbitkan. Skripsi. Jember: Program Studi ilmu Keperawatan Universitas Jember.

Indriyawati, I. 2010. Faktor-Faktor Ibu yang berhubungan dengan Pemberian Makanan Pendamping ASI (MP-ASI) Dini pada Bayi Usia $<6$ Bulan. Tidak diterbitkan. Skripsi. Semarang: Program Studi Ilmu Gizi Fakultas Kedokteran Universitas Diponegoro

Kementerian Hukum dan Hak Asasi Manusia. 2010. UNDANG-UNDANG NOMOR 13 TAHUN 2003. Edisi online. http:// peraturan.go.id/uu/nomor-13-tahun2003.html

Khoiriyah, A. \& Prihatini, R. 2011. Hubungan Antara Paritas Dengan Keterampilan Menyusui Yang Benar Pada Ibu Nifas. Jurnal Midpro. edisi $2 / 2011$. Online series: http://journal.unisla.ac.id/pdf/ 196220145.\%20Hubungan\%20antara\% 20paritas\%20dengan\%20ketrampilan\%
20 menyusui $\% 20$ yg $\% 20$ benar $\%$ 20pd\%20ibu\%20nifas.pdf.

Nasihah, M. \& Mahaijiran, D. 2010. Hubungan Antara Paritas Dengan pemberian Kolostrum Pada Ibu Post partum. Jurnal midpro vol. 2 / no. 2 /desember 2010. Online. http:/ /journal.unisla.ac.id/pdf/19222010/ 1.\%20hubungan $\% 20$ paritas $\% 20$ dengan $\%$ 20pemberian $\% 20$ kolostrum.pdf

Naylor, JA. \& Wester, R. 2009. Manajemen Laktasi. Edisi Ketiga. Penerjemah: Durjati, Sri., dkk. Jakarta: Perkumpulan Perinatologi Indonesia (Perinasia)

Kementerian Kesehatan Republik Indonesia. 2011. Profil Kesehatan Indonesia 2010. Jakarta: Kementerian Kesehatan RI. Online. http://www.depkes.go.id/resources/download/pusdatin/profilkesehatan-indonesia/profil-kesehatanindonesia-2010.pdf

Prawirohardjo, Sarwono. 2002. Pelayanan Kesehatan Maternal dan Neonatal. Jakarta: Yayasan Bina Pustaka

Purwanti. 2004. Konsep Penerapan ASI Eksklusif. Jakarta:EGC.

Ramaiah, S. 2006. Manfaat ASI dan Menyusui: Panduan Praktis bagi Ibu setelah Melahirkan. Jakarta: Buana Ilmu Populer.

Rohani. 2007. Pengaruh Karakteristik Ibu Menyusui Terhadap Pemberian ASI Eksklusif di Wilayah Kerja Puskesmas Teluk Kecamatan Secanggang Kabupaten Langkat. Skripsi. USU Repository. Online. http://repository.usu.ac.id/ bitstream/handle/123456789/14635/ 08E01518.pdf? sequence $=1$

Soetjiningsih. 2001. ASI Petunjuk untuk Tenaga Kesehatan. Jakarta: EGC

Sujudi, A. 2004. Keputusan Menteri Kesehatan Republik Indonesia Nomor 450/menkes/ sk/iv/2004 tentang Pemberian Air Susu Ibu (ASI) secara Eksklusif pada Bayi di Indonesia. Jakarta: Menteri Kesehatan Indonesia.

Sulistyoningsih, Hariyani. 2011. Gizi Untuk Kesehatan Ibu dan Anak. Yogyakarta: Graha Ilmu Suparyanto. 2010. Konsep paritas/partus. Edisi online. http://dr-suparyanto.blogspot.co.id/ 2010-/10/konsep-paritas-partus.html

Suradi, Rulina., Roesli, Utami. 2008. Manfaat ASI dan Menyusui. Jakarta: Balai Penerbit FK-UI 
Takasihaeng, Jan. 2005. Hidup Sehat Bagi Wanita:

Kumpulan Artikel Kesehatan Kompas.

Jakarta: Kompas

Yuliarti, N. 2010. Keajaiban ASI: Makanan Terbaik

Untuk Kesehatan, Kecerdasan dan Kelincahan Si Kecil. Yogyakarta: Andi. 